\title{
FATAL CONSEQUENCES OF THE USE/ABUSE OF PSYCHOACTIVE DRUGS
}

\author{
J. Sidlo ${ }^{1,2}$, P. Ocko ${ }^{1,2}$, L. Mikulas ${ }^{1,2}$, J. Sikuta ${ }^{1,2}$
}

Institute of Forensic Medicine, School of Medicine, Comenius University ${ }^{1}$

Institute of Forensic Medicine, Health Care Surveillance Authority Bratislava, Slovakia ${ }^{2}$

Key words: prescription of psychoactive drugs, drug related deaths, use/abuse, fatal intoxication, autopsy, toxicological analysis.

Clinical and experimental pathology. Vol.18, №2 (68). P.144-147.

DOI: $10.24061 / 1727$ 4338.XVIII.2.68.2019.254

E-mail: sidlo45@ gmail.com

\section{Ключевые слова:} реценттурные психоактивные nрепараты, смерть связаная с употреблением лекарств, употребление/ злоупотребление, смертельная интоксикация, aутопсия, токсикологический анализ.

Клиническая и экспериментальная патология Т.18, №2 (68). C.144-147.
Objective - the aim of the work was to ascertain occurrence of fatal intoxication caused by psychoactive drugs prescription in autopsy material of Bratislava forensic medical examination.

Materials and methods. The analysis of all cases of death in consequence of the overdose of the prescribed psychoactive drugs according to the results of autopsy at Bratislava forensic medicine workplaces within the period of the years $2001-2017$ was performed. Results. During the monitored period the criteria of inclusion coincided with 114 cases of fatal intoxications caused by psychoactive drugs prescription. Males comprised 59\% of all cases.

The age category over 35 years represented $81 \%$ of cases. Benzodiazepines were the most frequently detected as a main substance in $46 \%$ of cases. Combination with ethanol was found in 39\% of cases. In Bratislava region, $73 \%$ of the deaths were found. Suicide was detected in $67 \%$ of the cases, $55 \%$ of the deaths occurred in the domestic environment. Conclusion. The results of the analysis point to a high risk of benzodiazepine use/abuse, possibly combined with ethanol.

\section{ЛЕТАЛЬНЫЙ ИСХОД ИСПОЛЬЗОВАНИЯ/ЗЛОУПОТРЕБЛЕНИЯ ПСИХОАКТИВНЫМИ ЛЕКАРСТВЕННЫМИ СРЕДСТВАМИ}

\section{J. Sidlo, P. Ocko, L. Mikulas, J. Sikuta}

Цель работы - оценка летальной интоксикации, вызванной рецептурныли психоактивными веществами, по результатам судебно-медицинской экспертизы тел умерших в г. Братислава.

Материал и методы. Проводили анализ всех случаев смерти, что наступила в следствии передозировки психотропными рецептурными препаратами, по результатам судебно-медицинской экспертизы тел умерших в г. Братислава в период c 2001 no 2017 год.

Результаты. В период мониторинга критерии влючення совпали с 114 случаями смертельной интоксикаций, вызванной рецептурными психоактивными средствами. Мужчины составляли 59\% всех случаев. Возрастная категория свыше 35 лет составляла $81 \%$ случаев. Чаще всего (в 46\% случаев), как основное вещество, которое повлекло отравление, определяли бензодиазепины. Комбинация с этанолом встречалась в 39\% случаев. В Братиславском регионе обнаружено $73 \%$ смертей. 67\% случаев составляли самоубийства, в 55\% случаев смерть возникала в бытовых условиях.

Вывод. Результаты анализа указывают на высокий риск использования/злоупотребления бензодиазепинами, возможно, в сочетании с этанолом.

\section{Ключові слова: рецептурні психоактивні препарати, смерть пов'язана з вживанням ліків, вживання/ зловживання, смертельна інтоксикація, aymonciя,} ISSN $1727-4338$

\section{ЛЕТАЛЬНІ НАСЛІДКИ ВИКОРИСТАННЯ/ЗЛОВЖИВАННЯ ПСИХОАКТИВНИХ ЛІКАРСЬКИХ ЗАСОБІВ}

\section{J. Sidlo, P. Ocko, L. Mikulas, J. Sikuta}

Мета роботи - оцінка летальної інтоксикації, спричиненої рецептурними психоактивними речовинами, за результатами судово-медичної експертизи тіл померлих у м. Братислава.

Матеріал і методи. Проводили аналіз всіх випадків смерті внаслідок передозування психотропними рецептурними препаратами, за результатами судово-медичної експертизи тіл померлих у м. Братислава в період з 2001 по 2017 рік.

Результати. В період моніторингу критерії влючення співпали із 114 випадками 
токсикологічний аналіз.

Клінічна та експериментальна патологія Т.18, №2 (68). С.144-147. смертельних інтоксикацій, спричинених рецептурними психоактивними засобами. Чоловіки складали 59\% всіх випадків. Вікова категорія понад 35 років складала 81\% випадків. Найчастіше (в 46\% випадків), як основну речовину, щзо спричинила отруєння, визначали бензодіазепіни. Комбіначія з етанолом зустрічалась у 39\% випадків. У Братиславському регіоні виявлено 73\% смертей. 67\% випадків складало самогубство, 55\% випадків смерті виникала в побутових умовах.

Висновок. Результати аналізу вказують на високий ризик використання/ зловживання бензодіазепіном, можливо, в поєднанні з етанолом.

\section{Introduction}

Consumption of prescription psychoactive drugs in Slovak Republic has increased significantly in recent years [1,2]. Their use/abuse represents a serious health and social problem $[3,4]$. Analysis of its fatal consequences is one of the essential indicators of the seriousness of the problem.

\section{The goal of the work}

Aim of the work is to present results of retrospective prospective analysis of cases of direct psychoactive drugs prescription related with deaths in the period of years 2001 - 2017 in autopsy material of Bratislava forensic medicine workplaces.

\section{Materials and methods}

The study included all those deceased who died in relation to prescription psychoactive drug use / abuse in the territory of the Bratislava and Trnava regions (West Slovakia), what is a catchment area with approximately 1.2 million of inhabitants, which represents more than one fifth of the population of Slovakia, and were submitted to medico-legal autopsy and toxicological investigation at the Institute of Forensic Medicine of the Faculty of

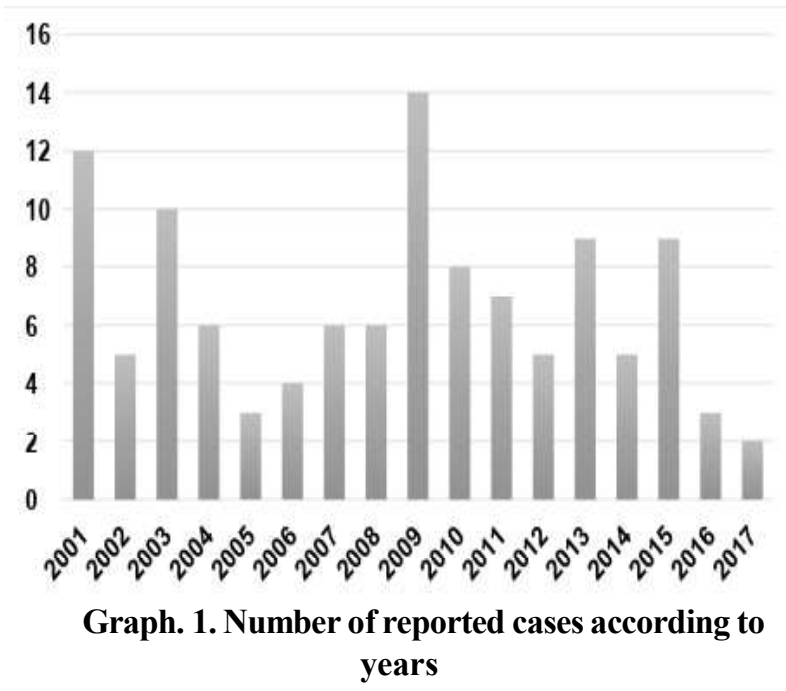

Most cases were in the 40 - 44 age group - 16 (14\%). The age category over 35 years represented $81 \%$ of cases (Graph 3).

The total number of foreign substances detected by qualitative and quantitative toxicological analyses far exceeded the number of cases. In 114 cases, 229 foreign substances were found, representing on average 2 substances per case. Except in cases where only one substance was detected, substances were found in two-, three- and four-fold combinations. Two substances were

Клінічна та експериментальна патологія. 2019. Т.18, №2 (68)
Medicine of Comenius University and the Institute of Forensic Medicine of Health Care Surveillance Authority in Bratislava within seventeen-year period of the years 2001 - 2017. Considering collected data obtained from autopsy reports, laboratory investigations, police reports and health documentation the cases were assessed according to occurrence of cases in particular years, sex, age, drugs detected, cause of death, external cause of death, place and district of death and availability of case history. Statistical analyses were made by means of SPSS software. The graphical presentation of the results was realized using Microsoft Office Excel 2016.

\section{Results and discussion}

During the monitored period, 15,737 autopsies were carried out in the mentioned workplaces. The criteria matched 114 cases $-0.7 \%$ of all performed autopsies. The incidence of cases in individual years ranged between 2 (2\%) in 2017 and 14 (12\%) in 2009 (Graph 1).

Evaluating the incidence of deaths in particular months of the year, the lowest incidence was observed in September $-3(3 \%)$, with the highest incidence of deaths in July - 17 (15\%) (Graph 2).

Males comprised $59 \%$ of all cases and females $41 \%$.

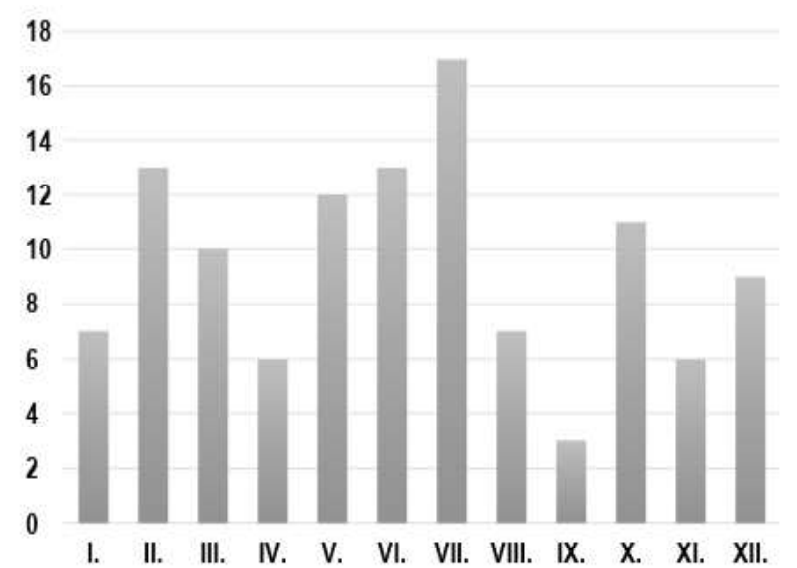

Graph. 2. Number of reported cases according to months of the year

found in $50 \%$ and combinations of substances totally in $73 \%$ of cases. Benzodiazepines were the most frequently detected as a main substance in $46 \%$ of cases, totally, in combination with other substances in $57 \%$ of cases. Combination with ethanol was found in $39 \%$ of cases, of which in $70 \%$ it was combined also with benzodiazepines. Graphs 4 and 5 show the occurrence of individual groups of substances according to ICD-10 codes and the ratio of cases with detected benzodiazepines to the total number of cases.

ISSN 1727-4338 https://ww.bsmu.edu.ua 


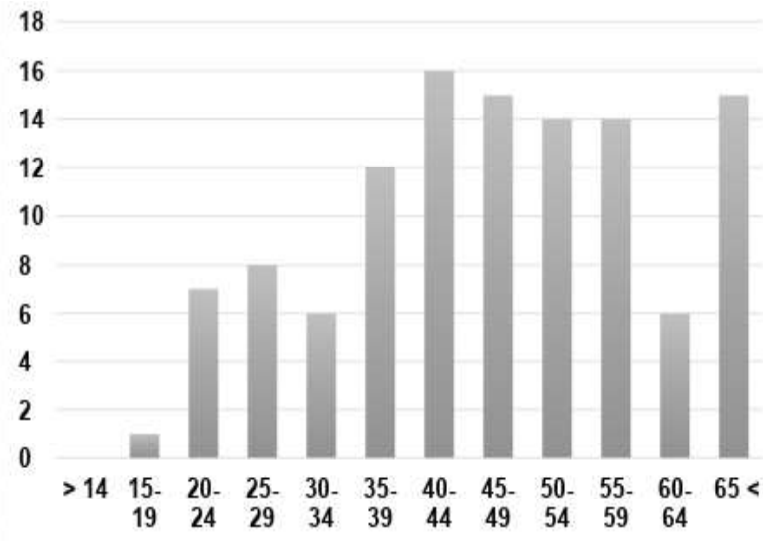

Graph. 3. Number of reported cases according to age categories

In Bratislava region, $73 \%$ of the deaths were found. External cause of death was suicide - in $67 \%$ of the cases, $55 \%$ of the deaths occurred in the domestic environment (Graph 6).

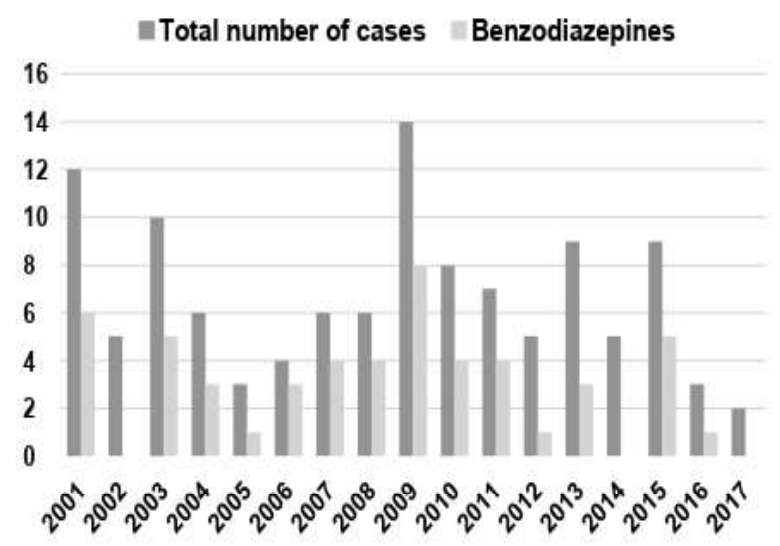

\section{Graph. 5. Rate of cases with detected enzodiazepines according to years}

\section{Conclusion}

The results of the analysis point to a high risk of benzodiazepine use / abuse, possibly combined with ethanol. The results of our study showed relatively high participation rate of prescription drugs on total number of fatal cases related to drug abuse. This fact highlights the need to pay more attention to the indication of the treatment and to control of prescription in treated psychiatric patients, especially those at risk of suicide.

\section{Literature}

1.Kriska M, Payer J, Novák I, Jezová D. Hodnotenie rizika liekov vo vzt'ahu $\mathrm{k}$ jeho percepcii. Klin Farmakol Farm. 2003;17(1):12-6.

2.Mamdani M, Herrmann N, Austin P. Prevalence of antidepressant use among older people: population-based observations. J Am Geriat Soc. 1999;47(11):1350-3. doi: 10.1111/ j.1532-5415.1999.tb07438.x

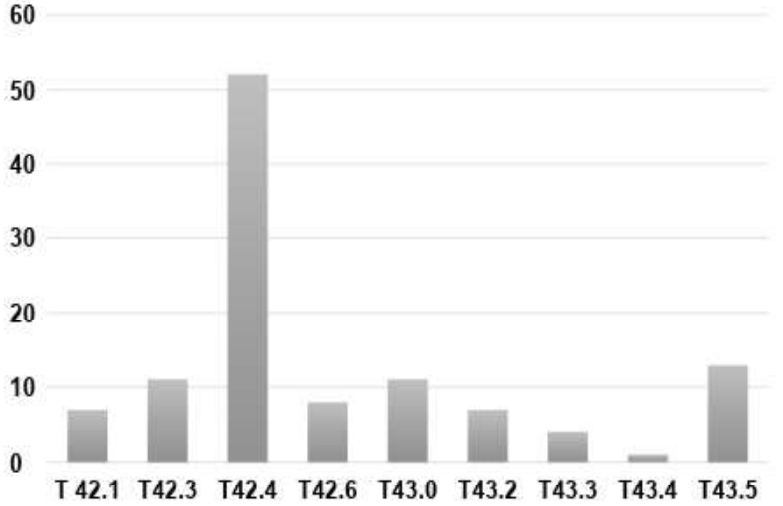

Graph. 4. Number of reported cases according to groups of detected drugs (in terms of ICD-10 codes)

Anamnestic data on the use / abuse of prescription drugs were not available in $59 \%$ of cases. In the case of a known history, there were chronic users / abusers in 8 (7\%) cases. Thirty-three persons (34\%) were psychiatric patients, of whom $24(62 \%)$ committed suicide.

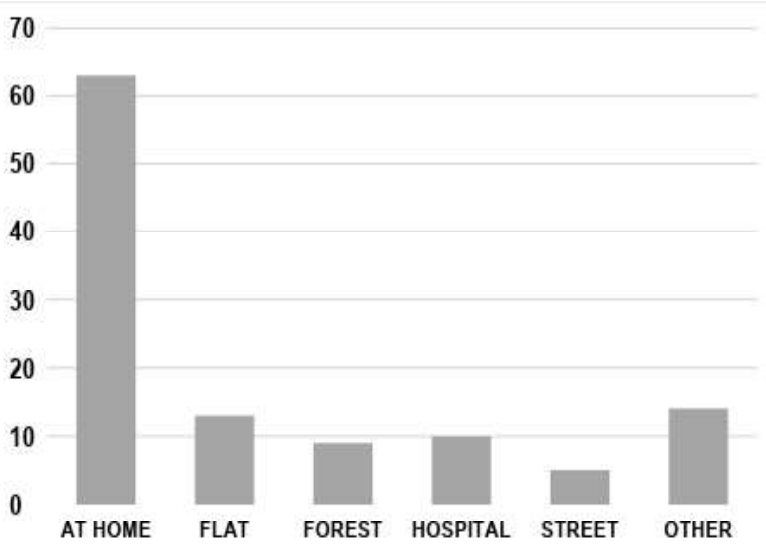

Graph. 6. Number of reported cases according to place of death

3.Foltán V, Cintala J. Lieková politika a jej reflexia v spotrebe liekov na Slovensku. Bratislava: SUKL; 2001. 98 p.

4. Hampl K. Lécba nebo distribuce drog? Alkohol Drog Záv. 2008;43(4):245-50.

\section{References}

1.Kriska M, Payer J, Novák I, Jezová D. Hodnotenie rizika liekov vo vzt'ahu $\mathrm{k}$ jeho percepcii [Risk assessment of drugs in relation to its perception]. Klin Farmakol Farm. 2003;17(1):12-6 (in Slovak).

2.Mamdani M, Herrmann N, Austin P. Prevalence of antidepressant use among older people: population-based observations. J Am Geriat Soc. 1999;47(11):1350-3. doi: 10.1111/ j.1532-5415.1999.tb07438.x

3.Foltán V, Cintala J. Lieková politika a jej reflexia v spotrebe liekov na Slovensku [Drug policy and its reflection on drug consumption in Slovakia]. Bratislava: SUKL; 2001. 98 p. (in Slovak).

4.Hamp1 K. Lecba nebo distribuce drog? [Drug treatment or distribution?] Alkohol Drog Záv. 2008;43(4):245-50. (in Czech).

\section{Відомості про авторів:}

Jozef Sidlo - доктор філософіï, доцент, керівник Інституту судової медицини Університету ім. Коменського, м. Братислава Словацька Республіка

Peter Ocko - заступник головного лікаря Судового центру Інституту контролю за наркотиками, м. Братислава Словацька Республіка 
L’ubomír Mikulás - лікар Судового центру Інституту контролю за наркотиками, м. Братислава Словацька Республіка Ján Sikuta - лікар Судового центру Інституту контролю за наркотиками, м. Братислава Словацька Республіка

\section{Сведения об авторах:}

Jozef Sidlo - доктор философии, доцент, руководитель Института судебной медицины Университета им. Коменского, г. Братислава Словацкая Республика

Peter Ocko - заместитель главного врача Судебного центра Института контроля за наркотиками, м. Братислава Словацкая Республика

L’ubomír Mikulás- врач Судебного центра Института контроля за наркотиками, г. Братислава Словацкая Республика Ján Sikuta - врач Судебного центра Института контроля за наркотиками, г. Братислава Словацкая Республика

\section{Information about the authors:}

Jozef Sidlo - MD, PhD., associate professor, Head of the Institute of Forensic Medicine Comenius University in Bratislava, Slovak Republic

Peter Osko - Vice President Medical Director of the Judicial Center of the Institute for Drug Control, Bratislava, Slovak Republic L'ubomír Mikulás - Doctor of the Judicial Center of the Institute for Drug Control, Bratislava, Slovak Republic Ján Sikuta - Doctor of the Judicial Center of the Institute for Drug Control, Bratislava, Slovak Republic 